\title{
KEGIATAN EKSTRAKURIKULER KESENIAN ANGKLUNG SEBAGAI SARANA PENGEMBANGAN PERILAKU CINTA TANAH AIR
}

\author{
Aryanti Dwi Untari \\ Universitas Banten Jaya \\ Serang, Indonesia \\ aryantidwiuntari@unbaja.ac.id
}

\begin{abstract}
The low sense of patriotism student at school became the focus of the problem in this research. In addressing this, schools have a very important role in imparts values and developing student's patriotism behavior through various programs and activities was held in schools. This study aims to find out how the extracurricular activities of angklung arts can be used as a means of developing patriotism behavior. By using descriptive qualitative method, this research will examine the extracurricular activities of angklung art in developing patriotism behavior in SMA Negeri 24 Bandung. The subjects in this study are students of SMA Negeri 24 Bandung who follow the extracurricular activities of angklung arts. The results showed that the extracurricular activities of angklung art at SMAN 24 Bandung were able to inculcate the noble cultural values through Sundanese cultural art, in which there are cultural values that can foster a sense of pride and love towards the homeland of Indonesia. This can be seen from the student's patriotism behavior which is reflected in the daily activities of the school.
\end{abstract}

Keywords: Patriotism, extracurricular, extracurricular of art, angklung

\section{PENDAHULUAN}

Fenomena globalisasi yang terjadi saat ini sudah tidak asing lagi terdengar di telinga kita. Globalisasi sudah pasti memberikan dampak bagi kehidupan kita, baik itu dampak positif maupun negatif. Syaifullah (2008, hlm.151) menyatakan bahwa "Intensitas dampak dalam setiap level tersebut, sudah barang tentu tidak sama, hal ini sangat dipengaruhi oleh sikap mental masyarakatnya dalam menerima atau menolak globalisasi tersebut." Dari pendapat tersebut dapat di uraikan bahwa kita tidak bisa menyalahkan kehadiran dari globalisasi, karena bagaimanapun juga pergantian atau regenerasi tetap diperlukan untuk menjaga kestabilan kehidupan manusia. Sehingga yang perlu di perhatikan dalam menghadapi arus globalisasi ialah sikap mental dari masyarakatnya dalam menerima atau menolak dampak negatif dari globalisasi tersebut.

M. Mastuhu (dalam Ma'mur asmani, 2011, hlm.5) mengungkapkan bahwa "globalisasi memberi peluang dan fasilitas yang luar biasa bagi siapa saja yang mau dan mampu memanfaatkannya, baik untuk kepentingan sendiri maupun kepentingan manusia seutuhnya." Berdasarkan pendapat tersebut, globalisasi memfasilitasi apa yang dibutuhkan oleh manusia, baik negatif maupun positif. Hal tersebut kembali lagi kepada mental masyarakat dalam menerima dan menolak berbagai peluang dan fasilitas yang tersedia sebagai dampak 
dari globalisasi. Apakah masyarakat itu siap dan mampu menjadi pemenang dalam kompetisi ini, sebab sejatinya globalisasi merupakan suatu kompetisi yang mencari seorang pemenang yang mampu memanfaatkan perkembangan positif dari segi pengetahuan, teknologi, pelayanan, dan

lain sebagainya, juga mampu menjadikan bangsanya sebagai bangsa produsen yang dapat berbicara banyak dalam hal

konteks dunia. Globalisasi sudah tentu memberikan dampak bagi yang mengikutinya, baik itu dampak positif maupun dampak negatif. Salah satu dampak positif dari globalisasi adalah kemajuan dan kemudahan dalam segala bidang. Dan salah satu dampak negatif dari globalisasi di Indonesia adalah menurunya karakter cinta tanah air generasi muda yang lebih menggandrungi budaya luar yang dianggapnya lebih modern dan berkelas.

Pembangunan budaya dan karakter bangsa (cultural and character building) merupakan komitmen nasional yang telah lama tumbuh dalam kehidupan berbangsa dan bernegara. Di era globalisasi ini, pembangunan budaya dan karakter bangsa sangat penting untuk dilaksanakan dalam berbagai aspek kehidupan. Pengaruh kebudayaan asing sebagai akibat dari globalisasi sangat mempengaruhi karakter bangsa khususnya bagi para generasi muda yang tidak lagi mengenal keanekaragaman budaya Indonesia.

Badan Pusat Penelitian dan Pengembangan Kementrian Pendidikan Nasional Republik Indonesia (dalam Yuliani, 2013, hlm. 3) mengemukakan bahwa:

"Harus adanya penanaman dan pembentukan karakter cinta tanah air dari mulai usia dini. Pembentukan karakter tersebut berada di lingkungan sosial dan budaya baik di lingkungan keluarga maupun di masyarakat. Alternatif lain yang banyak dikemukakan untuk mengatasi, paling tidak mengurangi, permasalahan diatas adalah melalui pendidikan".

Lembaga pendidikan memiliki tanggung jawab yang besar dalam mempersiapkan generasi penerus yang berkualitas dalam bidang ilmu, moral, dan mental untuk membangun negeri yang maju di segala bidang. Oleh karena itu, lembaga pendidikan harus menjadi garda terdepan dalam membina pendidikan karakter bagi anak. Sekolah sebagai lembaga pendidikan formal merupakan salah satu tempat yang memiliki peranan besar dalam pembentukan karakter dan perilaku seorang anak. Patut disadari bahwa sekolah memiliki beberapa komponen yang mampu membentuk 
karakter dan perilaku anak. Karakter dan perilaku positif peserta didik dapat dibangun bukan hanya melalui mata pelajaran yang diberikan kepada peserta didik di kelas namun juga dapat dibangun melalui berbagai kegiatan sekolah seperti kegiatan ekstrakurikuler, penerapan budaya sekolah, dan kegiatan pembiasaan sekolah.

Salah satu kegiatan yang berperan dalam pembentukan perilaku peserta didik adalah kegiatan ekstrakurikuler. Kegiatan ekstrakurikuler merupakan kegiatan pengembangan diri peserta didik yang diselenggarakan diluar jam belajar di kelas. Sebagaimana pengertian ekstrakurikuler dalam pedoman Ekstrakurikuler Permendikbud no. 62 tahun 2014 adalah sebagai berikut:

"Kegiatan kurikuler yang dilakukan oleh peserta didik di luar jam belajar kegiatan intrakurikuler dan kegiatan kokurikuler, dibawah bimbingan dan pengawasan satuan pendidikan, bertujuan untuk mengembangkan potensi, bakat, minat kemampuan, kepribadian, kerjasama dan kemandirian peserta didik secara optimal untuk mendukung pencapaian tujuan pendidikan".

Kegiatan ekstrakurikuler yang diselenggarakan pada satuan pendidikan memiliki berbagai fungsi yang sangat menunjang bagi peserta didik diantaranya ialah pembentukan karakter dan perilaku positif, pengembangan kepribadian, pengembangan minat bakat, pengembangan potensi diri, pengembangan soft skill dan hardskill, pengembangan kreativitas, melatih kemampuan berkomunikasi dan berinteraksi serta menunjang pengembangan karier.

\begin{tabular}{lcr}
\multicolumn{1}{c}{ Ruang } & lingkup & kegiatan \\
ekstrakurikuler & menurut & Direktorat \\
Pendidikan & Menengah & Kejuruan \\
menegaskan & bahwa & kegiatan
\end{tabular}
ekstrakurikuler harus berpangkal pada kegiatan yang dapat menunjang serta dapat mendukung program intrakurikuler dan program kokurikuler (dalam Suryosubroto, 2002, hlm. 272). Penyelenggaraan kegiatan ekstrakurikuler di setiap sekolah memiliki perbedaan, hal ini disesuaikan dengan kebutuhan dan kemampuan yang dimiliki oleh setiap sekolah. Kegiatan ekstrakurikuler memiliki berbagai jenis dan macamnya, diantaranya: ekstrakurikuler keagamaan, krida, karya ilmiah, kesenian, dan bentuk kegiatan lainnya.

Salah satu kegiatan ekstrakurikuler di sekolah yang mampu membangun jati diri peserta didik sebagai masyarakat berkebudayaan serta membangun karakter dan perilaku cinta tanah air adalah kegiatan ekstrakurikuler kesenian. Kegiatan ekstrakurikuler seni juga bertujuan untuk menumbuhkan rasa kepekaan siswa terhadap kesenian dan kebudayaan yang 
ada di dalamnya, mendalami budaya dan memperkenalkannya ke luar daerah bahkan ke kancah internasional, memupuk semangat generasi muda agar timbul rasa bangga terhadap adat budaya nusantara.

\section{METODE PENELITIAN}

Penelitian ini dilakukan di SMAN (Sekolah Menengah Atas Negeri) 24 Kota Bandung. Sekolah ini dijadikan pilihan dalam melakukan penelitian, sebab sekolah ini memiliki banyak sumber informasi yang dibutuhkan. Sekolah ini merupakan salah satu sekolah yang menerapkan dan melestarikan kearifan lokal di daerah setempat. Adapun jangka waktu penelitian ini dilaksanakan selama 2 bulan.

Subjek penelitian kualitatif merupakan pihak-pihak yang menjadi informan terhadap penelitian yang dilaksanakan. Adapun yang menjadi subjek dalam penelitian ini diantaranya: Wakasek Kesiswaan SMAN 24 Bandung, Pembantu wakasek ekstrakurikuler, guru Pendidikan Kewarganegaraan, guru pembina ekstrakurikuler kesenian, dan siswa.

Pendekatan yang digunakan dalam penelitian ini adalah pendekatan penelitian kualitatif, yakni penelitian yang dilakukan dengan mengumpulkan data-data, menganalisis data, dan menafsirkan data yang diperoleh melalui pengamatan sendiri. Sedangkan metode yang digunakan dalam penelitian ini adalah metode deskriptif. Penelitian ini bertujuan untuk membuat gambaran secara sistematis, faktual dan akurat mengenai fakta-fakta serta hubungan antar fenomena yang akan diteliti. Penulis memilih metode ini karena metode ini dianggap sesuai dengan masalah dan tujuan dari penelitian ini guna mendapatkan gambaran tentang perilaku cinta tanah air yang tercermin dalam diri peserta didik melalui kegiatan ekstrakurikuler.

Penelitian ini dilaksanakan melalui beberapa tahapan diantaranya adalah tahap pra penelitian, tahap pelaksanaan penelitian, dan tahap analisis data. Pada tahap pra penelitian, kegiatan awal yang dilakukan oleh peneliti adalah studi pendahuluan guna mengetahui apakah fokus penelitian ini layak untuk diteliti ataukah tidak. Setelah melakukan studi penelitian, peneliti membuat perizinan guna melangsungkan penelitian di tempat tersebut yaitu di SMA Negeri 24 Bandung. Setelah mendapatkan izin melaksanakan penelitian, peneliti menglangkah kepada tahap berikutnya yaitu tahap pelaksanaan penelitian. Pada tahapan ini peneliti mencari jawaban atas pertanyaan- 
pertanyaan yang telah disusun oleh peneliti untuk memecahkan fokus permasalahan yang ditetapkan dalam penelitian. Untuk tahapan selanjutnya adalah tahapan analisis data. Kegiatan analisis data ini dilakukan setelah seluruh data yang diperoleh.

Teknik pengumpulan data menggunakan wawancara, observasi, dan studi dokumentasi. Wawancara yang dilakukan adalah wawancara secara mendalam yang sifatnya terbuka kepada seluruh partisipan atau subjek penelitian untuk memperoleh infomasi yang relevan. Observasi dilakukan dengan cara mengamati langsung kegiatan ekstrakurikuler kesenian angklung dan sikap keseharian siswa di sekolag yang mengikuti ekstrakurikuler tersebut yang didukung oleh lembar observasi berupa pedoman observasi, lembar check list, dan catatan kecil. Adapun untuk memperkuat pengumpulan data melalui observasi dan wawancara adalah dengan menggunakan studi dokumentasi yaitu mengkaji dokumen-dokumen hasil kerja siswa, catatan kegiatan ekstrakurikuler siswa, dokumen partisipasi siswa dalam mengikuti ekstrakurikuler, serta kumpulan foto kegiatan ekstrakurikuler keseniang angklung.

Dalam penelitian kualitatif, yang menjadi instrumen dalam penelitian itu adalah peneliti sendiri. Seperti yang dikemukakan oleh Sugiyono (2009, hlm. 60), "Peneliti kualitatif sebagai human instrument, berfungsi menetapkan fokus penelitian, memilih informan sebagai sumber data, melakukan pengumpulan data, menilai kualitas data, analisis data, menafsirkan data, dan membuat kesimpulan atas temuannya". Dalam penelitian kualitatif belum dapat dikembangkan instrumen penelitian sebelum masalah yang diteliti jelas sama sekali, akan tetapi setelah masalah dalam penelitian itu sudah jelas, maka suatu instrumen dapat dikembangkan.

Dalam menganalisis data penelitian kualitatif deskriptif ini ialah dengan menggunakan analisis data penelitian berdasarkan Miles dan Huberman yang terdiri dari: mereduksi data, penyajian data, dan pengambilan keputusan. Miles dan Huberman dalam Sugiono (2012: 334), mengemukakan bahwa, "Aktivitas dalam analisis data kualitatif dilakukan secara interaktif dan berlangsung secara terus menerus sampa tuntas, sehingga datanya sudah jenuh". Untuk memeriksa keabsahan data yang diperoleh dari penelitian ini, peneliti melakukan uji keabsahan data secara teliti untuk dapat mempertanggung jawabkannya dari berbagai segi. Dalam pengujian keabsahan 
data, peneliti menggunakan tahapan uji keabsahan data menurut sugiono (2009, hlm. 121) meliputi "uji credibility (validitas internal), transferability (validitas eksternal), dependability (reliabilitas) dan confirmability (objektivitas).

\section{HASIL PENELITIAN DAN} PEMBAHASAN

Berdasarkan hasil observasi yang dilakukan oleh peneliti mulai dari pra penelitian sampai dengan pelaksanaan penelitian dapat diperoleh data mengenai kegiatan ekstrakurikuler kesenian angklung di SMAN 24 Bandung. Observasi yang dilakukan adalah secara langsung yaitu peneliti melihat langsung bagaimana kegiatan ekstrakurikuler kesenian angklung dapat dilaksanakan dalam upaya mengembangkan perilaku cinta tanah air siswa SMAN 24 Bandung.

Kesenian Angklung Buncis merupakan salah satu kesenian daerah Ujung Berung Bandung. Kesenian angklung buncis ini diterapkan di SMAN 24 Bandung melalui salah satu bentuk kegiatan di luar jam belajar sekolah yaitu kegiatan ekstrakurikuler kesenian angklung. Kegiatan ekstrakurikuler kesenian angklung ini berhasil dilaksanakan di SMAN 24 Bandung melalui proses pengenalan budaya daerah sebagai upaya meningkatkan rasa cinta tanah air siswa.

Sekolah ini memiliki dua ekstrakurikuler kesenian angklung yaitu ekstrakurikuler angklung buncis dan ekstrakurikuler angklung diatonis atau Harpa (Harmoni Paduan Angklung). Angklung Harpa ini bersifat nasional dan internasional karena membawakan lagulagu nasional maupun lagu internasional, sedangkan Angklung Buncis bersifat lokal karena Angklung Buncis ini merupakan salah satu kesenian khas Ujungberung.

Dalam kegiatan latihan rutin, seluruh anggota yang mengikuti latihan dibimbing oleh pelatihnya dan dipantau oleh Wakasek Kesiswaan. Seluruh anggota berbaris sesuai dengan ketentuan bermain angklung, sedangkan pelatih berada di depan sebagai instruktur untuk menyampaikan materi angklung dan memimpin anggota pemain angklung melalui gerak isyarat. Dalam mempersiapkan suatu pertunjukan angklung, pelatih memberikan latihan teknis dan keterampilan dalam memainkan angklung, pelatih juga membina mental seluruh anggota dalam mempersiapkan berbagai perlombasan atau pertunjukan angklung.

Antusisme siswa terhadap kegiatan ekstrakurikuler kesenian angklung ini 
sangat tinggi, hal ini terlihat dari jumlah anggota ekstrakurikuler kesenian angklung sangat banyak dibandingkan dengan ekstrakurikuler lain. Siswa yang mengikuti ekstrakurikuler ini terdiri dari siswa kelas XI dan Kelas XII yang berjumlah 66 siswa. Siswa kelas XII tidak lagi dilibatkan dalam ekstrakurikuler tersebut dikarenakan akan menghadapi dan mempersiapkan Ujian Nasional. Alasan siswa tertarik mengikuti ekstrakurikuler angklung karena ingin mempelajari lebih dalam mengenai kesenian angklung dan kesenian tersebut sangat menarik dalam berbagai pertunjukan.

Sedangkan berdasarakan hasil wawancara, peneliti memperoleh sejumlah data mengenai kegiatan ekstrakurikuler kesenian angklung di SMAN 24 Bandung. Data tersebut diperoleh dari hasil wawancara yang dilakukan melalui komunikasi langsung secara intensif dengan beberapa narasumber kunci yang ditemui di SMAN 24 Bandung. Dalam hal ini, narasumber yang berhasil di wawancarai oleh peneliti adalah sebagai berikut:

Tabel 1 Informan Penelitian

\begin{tabular}{lll}
\hline No & Nama & Jabatan \\
\hline 1 & Oom Romlah & Guru PPKn \\
2 & Deni Dimyati & Wakasek Kesis waan \\
3 & Sovi Rahmawati & Guru Pembina \\
& & Ekstrakurikuler \\
& & Kesenian Angklung \\
\hline
\end{tabular}

\begin{tabular}{lll}
\hline 4 & Hilman Abdurahman & $\begin{array}{l}\text { Pembantu Wakasek } \\
\text { Ekstrakurikuler }\end{array}$ \\
5 & Nanang Hidayat & Guru PPKn \\
6 & Karina K \& Alifa & Siswa XII IPA 1 \\
7 & Mira santi & Siswa kelas XI MIA \\
& & 5 \\
8 & Vani dan M. Fauzi & Siswa kelas X IIS 2 \\
9 & Aditya & Siswa kelas XI MIA \\
& & 4 \\
\hline
\end{tabular}

Adapun hasil penelitian dari proses wawancara tersebut dapat dikemukakan dalam deskripsi sebagai berikut ini:

Kegiatan ekstrakurikuler kesenian angklung memberikan pengaruh besar terhadap perilaku dan karakter siswa di sekolah. Perilaku tersebut dapat tercermin dalam kehidupan sehari-hari di lingkungan sekolah. Salah satu perilaku yang tercermin dari kegiatan ekstrakurikuler angklung adalah perilaku cinta tanah air. Bentukbentuk perilaku cinta tanah air yang tercermin dalam diri anggota ekstrakurikuler kesenian angklung diantaranya ialah ikut serta dalam setiap kegiatan peringatan hari besar nasional dengan menampilkan kesenian angklung, adanya kebersamaan dan toleransi antar teman, disiplin, tepat waktu, dan lain sebagainya. Hal tersebut dikemukakan oleh beberapa narasumber dalam proses wawancara, diantaranya sebagai berikut :

1) Deni Dimyati "Mental yang Kuat"

Menurut Deni Dimyati selaku wakasek kesiswaan, pengertian cinta tanah air secara sempit itu adalah cinta terhadap negaranya, dalam hal ini paling tidak siswa 
dapat mencintai almamater sekolahnya, tidak melakukan kesalahan yang membuat citra almamater sekolah menjadi tercoreng. Sekolah dijadikan sebagai miniatur negara, mendidik siswa untuk mencintai sekolahnya dan menjaga nama baik sekolah dengan seperti itu siswa akan belajar untuk mencintai negaranya

Ekstrakurikuler kesenian angklung merupakan sarana pengembangan kreativitas, bakat dan potensi siswa dalam bidang kesenian. Di SMAN 24 Bandung, kegiatan ekstrakurikuler kesenian lebih mengarah kepada kesenian daerah atau kesenian tradisional. Melalui ekstrakurikuler kesenian tradisional ini, penanaman nilai-nilai luhur budaya khususnya budaya sunda dapat diterapkan ke dalam diri siswa SMAN 24 Bandung.

Deni mengemukakan bahwa ekstrakurikuler kesenian yang diterapkan oleh sekolah ini berbeda dengan sekolah lainnya, sekolah ini hanya menerapkan ekstrakurikuler kesenian tradisional dan belum menerima atau belum mengizinkan ekstrakurikuler kesenian yang bersifat modern diterapkan di sekolah seperti cheerleaders, dance, dan lain sebagainya, karena kesenian modern seperti itu bertentangan dengan wawasan imtaq. Alasan sekolah menerapkan hal demikian adalah bertujuan untuk mempertahankan dan melestarikan budaya lokal, dengan mengenalkan siswa pada budaya-budaya daerah yang dimiliki. Hal ini sejalan dengan visi sekolah SMAN 24 Bandung yaitu mampu menghasilkan lulusan berwawasan Imtaq, berbudaya lingkungan, berakar budaya bangsa, dan mampu bersaing di Era Globalisasi. Dengan kata lain, sekolah ini sangat membantu upaya penanaman rasa cinta tanah air pada generasi muda sebagai penerus bangsa yang akan menentukan arah masa depan bangsa dan negara.

Deni menambahkan bahwa ekstrakurikuler memberikan pengaruh yang besar bagi pembentukan karakter anak, hal tersebut dapat dilihat saat anak akan menghadapi berbagai perlombaan dan kejuaraan. Saat mempersiapkan kejuaraan, mental anak akan dilatih dan dibina untuk menjadi mental yang kuat, yang siap menghadapi berbagai kemungkinan terjadi baik itu menang ataupun kalah. Dengan seperti itu, siswa siap menerima hasil dari kejuaraan tersebut. Kemudian siswa dibina untuk melakukan doa bersama sebelum melaksanakan latihan rutin sehingga siswa dapat terbiasa untuk melakukan doa terlebih dahulu sebelum melaksanakan berbagai kegiatan. Menurut Deni, siswa yang tidak mengikuti kegiatan ekstrakurikuler, pada umumnya cenderung 
lebih nakal dibandingkan dengan siswa yang mengikuti ekstrakurikuler meskipun tidak semua siswa bersikap dan berperilaku seperti itu.

2) Sovi Rahmawati "Menumbuhkan rasa cinta dan Bangga terhadap Budayanya"

Sovi mengemukakan bahwa setiap sekolah perlu mengenalkan budaya-budaya daerahnya, hal ini sangat penting untuk dilaksanakan di sekolah karena usia anak yang duduk di bangku sekolah adalah usia yang sangat cocok untuk mengenalkan dan memberi pemahaman bahwa betapa pentingnya budaya bangsa untuk dijaga dan dipelihara kelestariannya agar tidak di klaim oleh negara lain. Dengan seperti itu, anak akan menjiwai nilai-nilai budaya daerahnya sebagai bentuk rasa cinta terhadap tanah air Indonesia. Kegiatan ekstrakurikuler kesenian angklung ini dapat menjadi sarana untuk menumbuhkan rasa cinta dan bangga terhadap budayanya sendiri yang akan melandasi munculnya rasa cinta tanah air siswa.

Menurut Sovi, penanaman rasa cinta tanah air harus dimulai sejak dini saat anak belum terkontaminasi atau tercampur dengan budaya-budaya luar yang masuk melalui arus globalisasi. Dengan seperti itu, penanaman nilai-nilai budaya maupun penanaman rasa cinta tanah air dapat lebih cepat diserap dan diterima oleh seseorang.
Sovi memaparkan bahwa perwujudan sikap dan perilaku cinta tanah air siswa yang ditampilkan di sekolah adalah timbulnya rasa kekeluargaan antar siswa yang mengikuti ekstrakurikuler angklung. Dengan adanya rasa kekeluargaan tersebut siswa dapat saling menghargai, menghormati dan toleransi antar sesama.

Kemudian wujud perilaku cinta tanah air yang tercermin dalam diri siswa yang dijelaskan oleh Sovi adalah disiplin, Kedisiplinan siswa ini menunjukan sikap dan perilaku cinta tanah air yang tertanam dalam diri siswa. Dalam kegiatan ekstrakurikuler angklung khususnya dalam latihan rutin, siswa diwajibkan untuk hadir tepat waktu. Dengan seperti itu, siswa akan terbiasa untuk disiplin dan tepat waktu dalam kegiatan apapun. Berdasarkan pendapat Sovi tersebut, Deni menambahkan bahwa siswa yang mengikuti kegiatan ekstrakurikuler ini lebih taat terhadap aturan, patuh, dan tidak suka melakukan pelanggaran. Mereka patuh bukan hanya terhadap Pembina ekstrakurikuler saja, namun mereka juga patuh kepada seluruh guru dan aturan di sekolah. Sovi mengakui bahwa mereka yang mengikuti kegiatan ekstrakurikuler cenderung lebih santun terhadap guru maupun orang yang lebih tua. 
3) Nanang Hidayat "Sikap Menghargai Jasa Pahlawan"

Nanang Hidayat mengemukakan bahwa cara yang efektif dalam mengenalkan dan mendekatkan siswa dengan budaya daerah sebagai wujud dari cinta tanah selain melalui pedidikan seni budaya adalah melalui kegiatan ekstrakurikuler dengan cara memberikan keleluasaan kepada seluruh siswa untuk memilih ekstrakurikuler yang mereka minati. Karena ekstrakurikuler merupakan salah satu sarana pembentukan karakter siswa.

Menurut pendapat Nanang sikap yang ditampilkan oleh siswa dalam kehidupan sehari-hari di sekolah yang kaitannya dengan cinta anah air adalah adanya rasa peduli terhadap sesama, toleransi, disiplin, menghargai waktu, menghargai jasa-jasa pahlawan, dan mengikuti kegiatan upacara rutin hari senin. Sikap menghargai jasa pahlawan dapat dilihat dari partisipasi dan antusias siswa dalam mengikuti acara peringatan hari pahlawan atau acara-acara nasional lainnya. Sebagian besar siswa SMAN 24 Bandung ikut berpartisipasi aktif dalam memperingati hari besar nasional.

4) Hilman Abdurahman "Antusiasme Siswa dalam Mengikuti Esktrakurikuler Angklung"
Hilman memaparkan bahwa sikap kekeluargaan, kebersamaan, dan gotong royong sangat nampak dalam diri siswa yang mengikuti ekstrakurikuler angklung ini. Hal tersebut nampak saat mereka melakukan persiapan untuk mengikuti pertunjukan dan perlombaan, sebelum pemberangkatan mereka saling membantu untuk mempersiapkan peralatan angklung, kemudian bergotong royong untuk memindahkan alat dari ruangan ke dalam mobil, dan lain sebagainya. Sehingga persaudaraan diantara mereka terjalin begitu erat.

Menurut Hilman, sikap cinta tanah air siswa dapat tercermin dari rasa kebanggaan siswa terhadap kesenian angklung, hal ini di lihat dari antusiasme siswa dalam mengikuti ekstrakurikuler angklung. Kegiatan ekstrakurikuler angklung ini sangat diminati banyak siswa di SMAN 24 Bandung, hingga dalam penerimaannya pun kami mengadakan seleksi bagi siswa yang ingin mendaftar menjadi anggota angklung. Ekstrakurikuler angklung ini memiliki jumlah anggota yang sangat banyak dibanding dengan ekstrakurikuler lainnya. Selanjutnya, rasa bangga siswa terhadap kesenian angklung dimulai dari hal terkecil yaitu mereka mau merawat alat musik angklung tersebut dengan cara, membersihkannya, dan menjaga agar tidak 
terjatuh. Hal ini merupakan bentuk kecintaan siswa terhadap budayanya dan hasil karya bangsa Indonesia, karena alat musik angklung merupakan hasil karya bangsa asli Indonesia.

Hilman juga menambahkan bahwa dengan ikut berpartisipasi dalam berbagai kegiatan juga merupakan bentuk dari rasa cinta tanah air, contohnya saat perayaan kemerdekaan 17 Agustus 1945, SMAN 24 Bandung diminta untuk menjadi petugas pengibar bendera dan menampilkan salah satu karya seni yang dimiliki sekolah, maka kami pun menampilkan kesenian angklung.

Menurut pengamatan Hilman, siswa yang mengikuti ekstrakurikuler angklung memiliki sikap lebih lemah lembut, sopan santun dan tata kramanya lebih nampak dibandingkan dengan siswa yang mengikuti ekstrakurikuler lainnya seperti ekstrakurikuler yang bersifat fisik yaitu olah raga, karate dan lain sebagainya. Namun tidak berarti semua siswa yang mengikuti ekstrakurikuler yang bersifat fisik itu tidak memiliki sopan santun.

5) Oom Romlah "Tampil di Berbagai Acara-Acara hingga ke Mancanegara"

Oom mengungkapkan bahwa sikap tanah air siswa juga dapat dilihat dari siswa yang mengikuti upacara bendera atau menghormati bendera Indonesia, membersihkan lingkungan, menanam dan merawat tanaman di lingkungan sekolah, serta melestarikan budaya lokal. Salah satu sikap cinta tanah air yang tercermin dari kegiatan ekstrakurikuler angklung adalah melestarikan budaya lokal dengan menampilkan kesenian angklung dihadapan orang lain dengan tujuan untuk menunjukan kepada orang bahwa inilah budaya sunda yang kita miliki. Kegiatan ekstrakurikuler angklung ini sering mengikuti berbagai event atau acara-acara diluar sekolah, dengan seperti itu siswa dapat mengenalkan kesenian angklung kepada seluruh masyarakat bahkan hingga ke mancanegara, sehingga akan tertanam dalam diri siswa perasaan bangga terhadap kesenian tradisional tersebut.

6) Nadya Bella "Bangga dan Bersyukur menjadi Bangsa Indonesia"

Nadya Bella siswa kelas XII selaku anggota ekstrakurikuler angklung mengemukakan bahwa saya bangga dan bersyukur bisa menjadi orang Indonesia, karena Negara Indonesia memiliki banyak budaya unik dan mempunyai ciri khas tersendiri, yang belum tentu Negara lain memiliki budaya dan ciri khas unik dan beranekaragam seperti Negara Indonesia. Saya juga senang bisa bergabung di ekstrakurikuler angklung ini, karena saya bisa mendapatkan pengalaman di luar 
sekolah, bisa tampil di berbagai acara, dan mendapatkan wawasan yang banyak mengenai alat musik tradisional.

7) Karina dan Aditya "Sikap

Kepemimpinan"

Karina mengatakan bahwa "saya bangga dengan negara Indonesia karena tanah air saya memiliki warisan budaya yang tidak tertandingi indahnya. Saya juga senang bisa mengikuti dan tampil di berbagai pertunjukan dan perlombaan, setelah saya mengikuti perlombaan tersebut saya suka berbagi cerita mengenai pengalaman saya mengikuti pertunjukan dan berbagi mengenai kesenian angklung sehingga dapat menarik minat teman saya untuk mengikuti kegiatan ekstrakurikuler ini." Dalam ekstrakurikuler angklung ini tidak hanya diajarkan mengenai bagaimana bermain angklung saja, namun dalam ekstrakurikuler ini diterapkan nilai-nilai budaya angklung ke dalam diri siswa seperti toleransi dan kekeluargaan. Aditya menambahkan bahwa dalam ekstrakurikuler ini juga dibina sikap kepemimpinananya, yang mana sikap kepemimpinan tersebut diperoleh dari organisasi yang terdapat dalam ekstrakurikuler angklung.

8) Mira Santi, Ismi dan Vani "Adanya Perubahan Sikap"
Mira mengemukakan bahwa mengikuti ekstrakurikuler angklung ini dapat meningkatkan rasa cinta tanah air saya dengan tetap melestarikan kesenian angklung dengan cara mempelajari lebih dalam mengenai kesenian angklung, mencoba untuk mempelajari kesenian atau kebudayaan daerah lainnya, dan mencoba untuk mempopulerkan kesenian daerah terutama angklung. Mira siswi kelas XI selaku bendahara dalam ekstrakurikuler angklung, ia menyatakan bahwa dalam kegiatan ekstrakurikuler ini terdapat perubahan sikap yang terjadi seperti sikap lebih teliti, saling menghargai, adanya rasa kebersamaan, kekeluargaan, kesabaran, dan lain-lain. Ismi menambahkan bahwa dengan kita mencintai kesenian angklung saja berarti kita sudah budaya daerah, dengan kita mencintai budaya daerah berarti kita mencintai tanah air Indonesia. Bentuk cinta tanah air kita dapat ditunjukan dengan cara tetap memainkan angklung, memperkenalkan kesenian angklung kepada khalayak banyak baik itu bangsa Indonesia maupun bangsa asing dan memperdalam budaya Indonesia lainnya. Vani siswi kelas $\mathrm{X}$ juga berpendapat bahwa kita harus menunjukan kebudayaan yang kita miliki salah satunya adalah kesenian angklung, agar masyarakat luar mengetahui bahwa kesenian angklung itu 
merupakan hasil budaya yang sangat berharga dan perlu dilestarikan.

Bebagai pendapat dari beberapa anggota ekstrakurikuler tersebut menunjukan sikap dan perilaku cinta tanah air yang mereka peroleh melalui kegiatan ekstrakurikuler angklung. Perilaku dan sikap yang ditunjukan oleh siswa yang mengikuti ekstrakurikuler berbeda dengan siswa yang tidak mengikuti kegiatan ekstrakurikuler sama sekali.

Adapun bentuk-bentuk perilaku cinta tanah air yang tercermin dalam diri siswa yang mengikuti kegiatan ekstrakurikuler angklung di SMAN 24 Bandung dapat dilihat pada table berikut:

Tabel 2. Bentuk perilaku cinta tanah air yang tercermin dalam diri siswa

\begin{tabular}{|c|c|c|}
\hline No & $\begin{array}{l}\text { Bentuk } \\
\text { Perilaku }\end{array}$ & Sikap yang Tercermin \\
\hline 1 & $\begin{array}{l}\text { Rasa } \\
\text { kebanggaan }\end{array}$ & $\begin{array}{l}\text { Antusias siswa dalam } \\
\text { mengikuti kegiatan } \\
\text { ekstrakurikuler angklung } \\
\text { dan berusaha untuk } \\
\text { mempopulerkan kesenian } \\
\text { angklung melalui } \\
\text { berbagai pertunjukan }\end{array}$ \\
\hline 2 & $\begin{array}{l}\text { Kekeluargaan } \\
\text { dan } \\
\text { kebers amaan }\end{array}$ & $\begin{array}{l}\text { siswa yang bersikap } \\
\text { tidak individualis dan } \\
\text { mau berbaur dan } \\
\text { berteman dengan siapa } \\
\text { pun tanpa membedakan } \\
\text { ras, suku, dan agama }\end{array}$ \\
\hline 3 & Kerja sama & $\begin{array}{l}\text { Siswa yang memainkan } \\
\text { angklung harus bisa } \\
\text { bekerja sama dengan } \\
\text { baik untuk menjaga } \\
\text { keharmonisan dan } \\
\text { keindahan sebuah lagu }\end{array}$ \\
\hline 4 & Ketelitian & Siswa yang memainkan \\
\hline
\end{tabular}

\begin{tabular}{|c|c|c|}
\hline & & $\begin{array}{l}\text { angklung harus teliti dan } \\
\text { fokus dalam } \\
\text { mendengarkan intruks } \\
\text { yang diberikan conducter } \\
\text { agar tidak terjadi } \\
\text { kesalahan karena satu } \\
\text { orang mempengaruhi } \\
\text { orang banyak }\end{array}$ \\
\hline 5 & Toleransi & $\begin{array}{l}\begin{array}{l}\text { Perilaku siswa yang } \\
\text { berusaha }\end{array} \\
\text { memahami antara siswa } \\
\text { satu dengan yang lainnya } \\
\text { agar terjaga } \\
\text { keharmonisan anggota } \\
\text { ekstrakurikuler angklung }\end{array}$ \\
\hline 6 & Disiplin & $\begin{array}{lr}\text { Siswa yang mentaati } \\
\text { aturan } & \text { khususnya } \\
\text { peraturan } & \text { saat } \\
\text { pembelajaran angklung }\end{array}$ \\
\hline 7 & $\begin{array}{l}\text { Tanggung } \\
\text { Jawab }\end{array}$ & $\begin{array}{l}\text { Siswa giat melaksanakan } \\
\text { kewajibannya sebagai } \\
\text { pemain angklung untuk } \\
\text { mengikuti kegiatan } \\
\text { latihan rutin. }\end{array}$ \\
\hline
\end{tabular}

Berdasarkan data yang diperoleh dari hasil penelitian bahwa Ekstrakurikuler kesenian angklung merupakan sarana pengembangan diri siswa yang dapat mengasah bakat dan potensi siswa dalam bidang kesenian. Di SMAN 24 Bandung, kegiatan ekstrakurikuler kesenian lebih mengarah kepada kesenian daerah atau kesenian tradisional. Melalui ekstrakurikuler kesenian tradisional ini, penanaman nilai-nilai luhur budaya khususnya budaya sunda dapat diterapkan ke dalam diri siswa SMAN 24 Bandung.

Penanaman nilai-nilai luhur budaya kepada siswa melalui kegiatan 
ekstrakurikuler merupakan cara yang tepat untuk membangkitkan semangat kebangsaan dan cinta tanah air siswa disamping melalui proses pembelajaran di kelas. Kegiatan ekstrakurikuler kesenian angklung ini terbukti dapat membentuk dan membina perilaku cinta tanah air dalam diri siswa. Berdasarkan hasil penelitian yang dilakukan oleh penulis di SMAN 24 Bandung, bentuk-bentuk perilaku cinta tanah air siswa yang tercermin dalam kehidupan sehari-hari adalah timbulnya rasa bangga terhadap budaya Indonesia, sikap kepemimpinan, kebersamaan, kekompakan, kekeluargaan, kerjasama, toleransi, saling menghargai dan tanggung jawab.

Rasa cinta tanah air merupakan konsep yang sangat sempit karena rasa cinta tanah air merupakan perwujudan dari rasa nasionalisme. Menurut Suteng Bambang (2002:21) "Nasionalisme adalah sikap mental dan tingkah laku individu atau masyarakat yang menunjukan adanya loyalitas atau pengabdian yang tinggi terhadap bangsa atau memelihara kehormatan bangsa." Loyalitas dan pengabdian suatu bangsa terhadap negaranya dapat ditunjukan dengan menjaga dan memelihara apa yang dimiliki oleh Negara Indonesia dan tetap mempertahankan keutuhan Negara.
Ciri-ciri dari sikap nasionalisme dapat diuraikan sebagai berikut: Memiliki rasa cinta tanah air Indonesia, Bangga dan menghargai seluruh keanekaragaman Indonesia, Menjaga dan melestarikan seluruh kekayaan nusantara, Mencintai produk dalam negeri, Bersedia mempertahankan dan memajukan negara Indonesia, Menyadari sepenuhnya sebagai bagian dari bangsa Indonesia, dan Mengutamakan kepentingan bersama dibandingkan kepentingan pribadi atau golongannya

Rasa cinta tanah air juga diperkuat dengan adanya semangat kebangsaan untuk tetap menjaga kesatuan dan keutuhan negaranya. Rasa cinta dan bangga terhadap tanah air juga merupakan salah satu komponen nilai-nilai karakter. Pendidikan karakter bangsa sangat penting dan memberikan pengaruh yang besar tehadap kemajuan suatu Negara, karena kemajuan suatu bangsa ditentukan oleh mental bangsa itu sendiri dalam menghadapi berbagai ancaman yang akan datang baik dari luar atau dalam Negara itu sendiri.

Pendidikan menjadi media yang paling efektif dalam mewujudkan berbagai tujuan, termasuk tujuan mencetak manusiamanusia yang berkarakter. Pendidikan Karakter tertuang di dalam mata pelajaran Pendidikan Kewarganegaraan (PKn), yang 
mana mata pelajaran tersebut mengusung mengenai wawasan kebangsaan atau karakter cinta tanah air.

Pengembangan karakter cinta tanah air ini dapat dibentuk melalui proses pembelajaran, baik yang berlangsung di dalam maupun diluar kelas pada setiap mata pelajaran. Pengembangan karakter cinta tanah air yang dilakukan di luar proses pembelajaran di kelas dapat dilaksanakan melalui kegiatan ekstrakurikuler. Kegiatan ekstrakurikuler yang mampu menanamkan karakter cinta tanah air adalah ekstrakurikuler kesenian angklung. Pendidikan karakter cinta tanah air berhasil diterapkan di SMAN 24 Bandung melalui kegiatan ekstrakurikuler kesenian angklung.

Kesenian angklung yang diterapkan melalui kegiatan ekstrakulikuler di sekolah menjadi suatu sarana dan media alternatif dalam menumbuhkan rasa cinta tanah air siswa dalam bentuk pelestarian budaya lokal khususnya budaya daerah. Seni budaya yang diterapkan di sekolah merupakan karakteristik budaya dimana siswa tersebut berada. Sebagaimana yang dikemukakan oleh Alwasilah dkk (2009, hlm.53) bahwa "Lembaga pendidikan bukan hanya sebagai pusat belajar dan mengajar, tetapi juga sebagai pusat penghayatan dan pengembangan budaya, baik budaya lokal, nasional, bahkan global".

Pendapat tersebut menjelaskan mengenai lembaga pendidikan sebagai tempat berjalannya proses belajar mengajar yang juga dapat dijadikan tempat penghayatan dan pengembangan budaya. Di dalam lembaga pendidikan inilah peserta didik mulai diperkenalkan dengan budaya lokal yang mereka miliki. Hal inilah yang disebut dengan etnopedagogik yakni pendidikan berbasis kearifan lokal.

\section{KESIMPULAN}

Kegiatan ekstrakurikuler kesenian angklung memberikan kontribusi terhadap pengembangan perilaku cinta tanah air siswa. Penanaman nilai-nilai luhur budaya kepada siswa melalui kegiatan ekstrakurikuler merupakan cara yang tepat untuk membangkitkan semangat kebangsaan dan cinta tanah air siswa disamping melalui proses pembelajaran di kelas. Kegiatan ekstrakurikuler kesenian angklung ini terbukti dapat membentuk dan membina perilaku cinta tanah air dalam diri siswa. Adapun bentuk-bentuk perilaku cinta tanah air siswa yang tercermin dari kegiatan ekstrakurikuler angklung di SMAN 24 Bandung adalah sebagai berikut: Rasa Kebanggaan, kekeluargaan dan 
kebersamaan, kerja sama, ketelitian, toleransi, disiplin dan tanggung jawab.

\section{c. Perundang-undangan}

Permendikbud no. 62 tahun 2014 mengenai Kegiatan Ekstrakurikuler pada Pendidikan Dasar dan Pendidikan Menengah

\section{DAFTAR PUSTAKA}

\section{a. Buku}

Alwasilah, dkk. 2009. Etnopedagogi Landasan Praktek Pendidikan dan Pendidikan Guru. Bandung: Universitas Pendidikan Indonesia

Ma'mur Asmani, Jamal. 2011. Buku Panduan Internalisasi Pendidikan Karakter di Sekolah. Yogyakarta: Diva Press.

Sugiyono. 2009. Memahami Penelitian Kualitatif. Bandung: Alfabeta.

Suryosubroto, B. 2002. Proses Belajar Mengajar di Sekolah. Jakarta: PT Rineka Cipta.

Suteng, Bambang. 2002. Pendidikan Kewarganegaraan kelas $X$. Jakarta: Erlangga.

Syaifullah. 2008. Ilmu Kewarganegaraan (Civics). Bandung: Laboratorium Pendidikan Kewarganegaraan Fakultas Pendidikan Ilmu Pengetahuan Sosial Universitas Pendidikan Indonesia

\section{b. Skripsi}

Yuliani, A. 2013. Implementasi Kegiatan Ekstrakulikuler Kesenian Tari Topeng Cirebon dalam Meningkatkan Rasa Cinta Tanah Air Siswa Sekolah Dasar(Studi Deskriptif pada Ektrakulikuler Kesenian Tari Topeng Cirebon di SD Negeri 3 Arjawinangun Kabupaten Cirebon). Skripsi Sarjana Jurusan Pendidikan Kewarganegaraan FPIPS UPI Bandung: Tidak diterbitkan. 